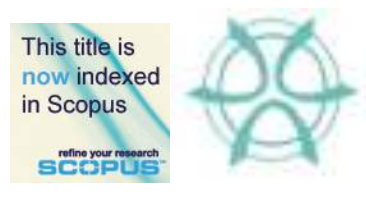

PLANNING MALAYSIA:

Journal of the Malaysian Institute of Planners

SPECIAL ISSUE IV (2016), Page 87 - 98

\title{
TRIPOGRAPHIC ASSESSMENT OF VFR TRAVEL IN CONTEXT OF MALAYSIAN DOMESTIC TRAVELERS
}

\author{
Sharifah Eisyahtun Syed Darar ${ }^{1} \&$ Hairul Nizam Ismail ${ }^{2}$ \\ ${ }^{1,2}$ Faculty of Built Environment \\ UNIVERSITI TEKNOLOGI MALAYSIA
}

\begin{abstract}
VFR travel is a form of travel that involves visiting family and friends as purpose of visit, or as part of activity. Travelling with the purpose of VFR has been recorded as the main purpose of travel for Malaysian domestic travel market in 2014 where the $46 \%$ travelers are travelling for this purpose. However, there is less study in this market especially in context of Malaysian domestic market. Past study has shown that this market seems to be neglected because it did not seem to give a huge impact economically. This market was assumed not utilizing tourism services and not participating in tourism activity. This paper is aim to examine the tripographic of VFR travelers where it assess the trip characteristic of VFR travel in order to have a better understanding of this market in context of domestic travelers. A survey was carried in selected area that packed with domestic travelers. Data obtained used in comparing the trip characteristics among VFR market travelers and nonVFR travelers. This result is useful for marketing strategy and a key planning for tourism destination.
\end{abstract}

Keyword: Visiting Friends and Relatives, VFR travel, trip characteristics

\section{INTRODUCTION}

Tourism industry is one of well-known industry all over the world because it involved many forms of tourism activities ranging from world tour to short trips, from leisure to business purposes. Since the industry has expanded widely around the world, it has become an important industry as it able to generate income and creates job opportunities. By the different types of purpose, the tourists fall under several type of tourism and do differ in their behavior. The different of their behavior will lead to differences in their spending pattern and influence the impact of economy in the area they visited.

Tourist frequently encountered classification by the purpose of visit. The United Nation of World Tourism Organization (2008) proposed the following classification which is personal and business. It is described as Figure 1. Most of the studies today focus on personal which is vacation, leisure and recreation tourist compared to the other form of tourist because this form of tourist are the only type that strictly participate the tourism activities and using the tourism facilities. They were seeing as ones who makethe highest spending on the area that they visited as compared to other segment. So it is crucial to 
Sharifah Eisyahtun Syed Darar \& Hairul Nizam Ismail

Tripographic Assessment of VFR Travel in Context of Malaysian Domestic Travelers

know either the other form of tourist such as visiting friends and relatives did make a contribution to the area that they visited.

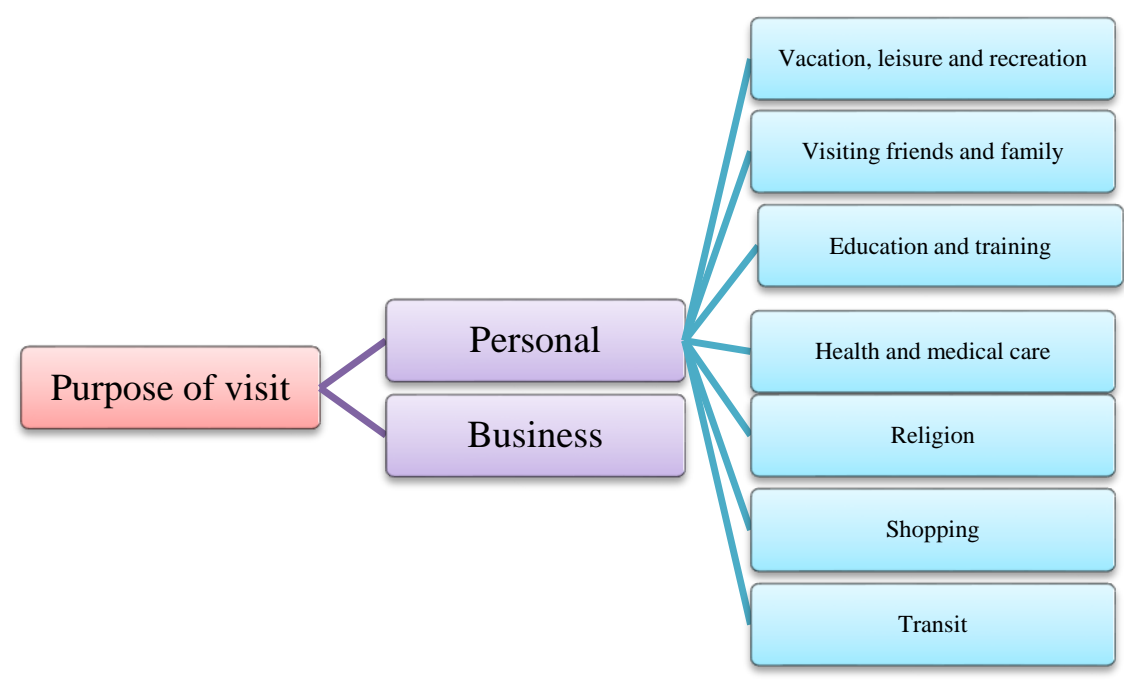

Figure 1: Tourist Classification by the Purpose of Visit

\section{BACKGROUND OF STUDY}

Tourism industry in Malaysia is one of main contributor economically. Data shows that 18.8 million of tourist arrival in Malaysia from January to September 2013 and generate RM 46.6 billion (Bernama, 2013). This shows that tourism player keep on improvising their strategies in promoting Malaysia as one of tourist destination. Not only that, they also promoting domestic tourism as well. The rate exchange of Malaysia hotel guest increase 7.8 percent in 2012, which almost 30 million of hotel guest for domestic tourist (Tourism Malaysia, 2013). It can be concluded that domestic tourist also did contributed to the Malaysia economy.

Population growth among the country is one of main reason why this VFR market seems to expand. From census that has been conducted by Department of Statistical Malaysia shows that the growth rate of Malaysian increased 2.0 percent which the total population in Malaysia on 2010 is 28.3 million. It is normal when people start to move from their hometown for different types of purpose such as job's requirement, furthering study or even seeking for new environment. In rural area especially, it is such a trend where the younger generation tend to seek for job opportunities far away from their home. Their friends and relatives left make population. So as the population grows, VFR market grows as well. Almost half of Malaysia domestic traveler categorized as VFR market where their primary purpose is for visiting friends and relatives according to Malaysia department of consensus. Data shows that the highest trips were made during festive seasons and school holidays.

There are many factors that encourage this group visit their family and friends regularly. From holidays and festivals, accessibility, to increase price of accommodation may contribute them to visit and/or stay with their families and friends. However, it is 
still lack information regarding on this group of people especially in Malaysia. Research on participation or non-participation behavior offers one means of assessing the latest demand for tourism in which it is essential for tourism policy maker and planner $(\mathrm{Wu}$, Zhang, \& Fujiwara, 2011)

This research attempts to analyze the tripographic of VFR travelers in context of Malaysian domestic market segments. As stated by Ramachandran (2006), this type of traveler not only visiting their friends and relatives, but also contributes to the bigger picture of tourism. This research will help tourism player on providing suitable activities and facilities for them by valuable information they provided

\section{VFR TOURISM}

Visiting friends and relatives are activity involve visiting friends and family that includes attending wedding, funerals or any family events which include short term caring of sick or old (WTO, 2008). VFR has been recognized as large form of tourism worldwide, and one of the oldest form of travel which was stated by Backer in 2011. She also concluded that VFR travel is a form of travel that involves visiting friends and/or relatives and where friend's or relative's accommodations being used. This is because the travelling to visits friends and family is important socially. The study relates to this type of tourism started in 1990 where Jackson in his article about the international VFR travelers in Australia creating a new wave of VFR market analysis where he stated that this particular market and their contribution has been underestimated. Since then, it is resulting in a succession study stresses on VFR. Jackson stated that VFR market was neglected since those travelers categorized themselves as leisure vacationers therefore leading to overlooked of this travelers in official figures. Since 1990, a content review regarding on VFR market identified that it is only 46 papers that relates specifically on this market (Griffin, 2013).

\section{VFR MARKET MODEL: PURPOSE OF VISIT AND ACCOMMODATION}

As explained before, VFR travel is a form of travel that involves the purpose of trip or the type of accommodation involves visiting friends and relatives. For the trip characteristics purpose, it shows that friends and relatives do influence the choice of accommodation of travelers especially for this market. Some reason could be for trip cost saving and hosting. The VFR market can be presented through this model: 
Sharifah Eisyahtun Syed Darar \& Hairul Nizam Ismail

Tripographic Assessment of VFR Travel in Context of Malaysian Domestic Travelers

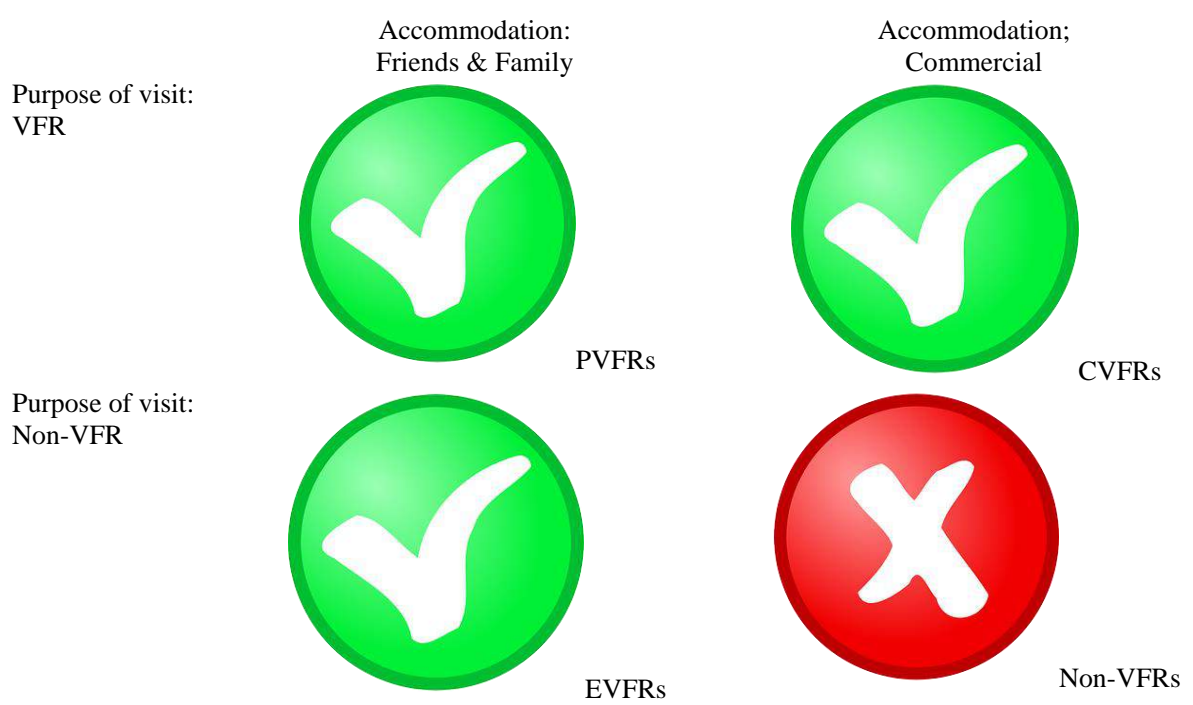

Figure 2: VFR Travel Definitional Model

The model above described that the VFR market fall into three typologies based on the accommodation and the purpose of visit( Backer, 2007). The first one is PVFRs which called the pure VFR where the purpose of visit and the accommodation purely with friends and relatives. Next is CVFRs or commercial VFR where the purpose of visit is visiting friends and relatives but they are having commercial accommodation during the visit. The EVFRs are the group who has other main purpose of visit besides VFR but they staying with them. Jokingly, it has been considered as exploiting their friends and relatives for accommodation used and having other purpose of visit.

\section{RESEARCH GAP}

Research from past paper shows that visiting friends and relatives travel was underestimated and ignored (Braunlich \& Nadkarni, 1995; Jackson, 2003; Morrison \& Leary, n.d., 1993). The awareness about this market was raised after Jackson (1990) in his seminal article about the potential of this market on the tourism industry. Paci (1994) have stated that VFR market was poorly documented which result to neglect of this market. Seaton and Palmer (1997) added the perceptions about this market are which are low economic impacts and cannot be influence by tourism planners and marketing. There are eight reasons why this market was ignored before as stated by Backer (2010);

i. $\quad$ VFR travel definition difficulties caused by few attempt to define VFR travel.

ii. Different VFR typologies lead to discrepancy of result based on the tool of measurement and model.

iii. Difficult segment to measure as they may not only stay with friends and relatives. They also involve hosting activity that lead to additional expenditure for this market from the host.

iv. This market was having a less attention from DMOs as a part of their target market 
v. VFR traveler does not give a significant impact economically towards the area that they have been visited

vi. VFR travel has been neglected as a syllabus in a textbook

vii. As the market tend to be ignored, tourism marketers assumed that this market cannot be influenced

viii. VFR is a 'poor cousin' of tourism industry as compared to leisure and international tourism industry.

From the reasons above shows that the problems on VFR market segment involve from many party not only from them. Host, DMOs, scholar and etc. should give a proper attention towards this market since some of research proves that this market did give significant impact on the destination specifically and industry generally.

\section{RESEARCH PROBLEMS}

Research on tourist characteristics has been conducted by many researchers in many areas. However it still has limited perspectives from the view of specific market segments. Awareness about the potential of this market rose after Jackson (1990) questioned on how this market was underestimated and the contribution of this market. From the view of travelers, they assumed that they are pleasure vacationers which result to small proportion of VFR market data, meaning that the number of VFR market may actually bigger than the number shown. Not only that, tourism players like DMOs assumed that this market not utilizing major tourism services like commercial accommodation and not participating in tourism activity. However, in the case of Malaysia, this type of traveler represents the highest number of total domestic travelers. This was clearly indicated from the view of visiting friends and relatives which their purpose of travel being reported as major motivation domestic pleasure travel in Malaysia according to Statistical Department of Malaysia during 2013. Apart from that, as a country who celebrates many types of holidays and celebrations, this factors influence its citizens to travel more often by many different kind of motives. There is also less number of research on Malaysian VFR market based on typologies proposed by researchers before as many study also trying to develop many models on typologies of VFR market. Study on their trip characteristics will help in determining their tourism participation and expenditure that will explain their contribution on the destination that they has been visited besides to have better understanding on their trip

\section{RESEARCH QUESTION}

This research aim is to examine the tripographic factors of VFR travel in the context of Malaysia domestic market travelers, it will address the following question:

i. How much percentage representing the number of VFR travelers from the total of domestic travelers?

ii. Does the VFR travelers travels more often as compared to other travelers that has different kind of motives?

iii. Does the VFR travelers in Malaysia utilizing commercial accommodation?

iv. How do they spend during their trip to the destination? 
Sharifah Eisyahtun Syed Darar \& Hairul Nizam Ismail

Tripographic Assessment of VFR Travel in Context of Malaysian Domestic Travelers

\section{RESEARCH AIM AND OBJECTIVES}

The aim of this research is to examine the tripographic factors of VFR travel in context of Malaysian domestic market segments. The 'Tripographic' term was introduced by $\mathrm{Hu}$ \& Morrison (2002) that described as an analysis of trip characteristics which more convenient term to use. The aim will address to the following objectives:

i. To determine domestics travelers trip characteristics

ii. To identify the trip characteristics among VFR market segments

iii. To compare the trip characteristics of VFR market and non-VFR markets

\section{RESEARCH METHODOLOGIES}

The data of this research was collected by using survey instrument at the end of school holidays. Quantitative research was used to gather data on domestic Malaysian travelers who just visited Johor and on the journey back to their residential. The purpose of choosing this domestic segment is to get the results that reflect the state of Johor. To make sure only this particular segment will answering this questionnaire, the respondent firstly will be asked either they just began their trip to north or on their way back to their home. The questionnaire paper consists of socio-demographic, trip-characteristics and average daily expenditure of domestic traveler.

This survey was conducted for two days at the rest and service area (RSA) or 'Rehat\&Rawat' (R\&R) stop point in Projek Lebuh Raya Usaha Sama Berhad or PLUS expressway Northbound, located in Pagoh. The R\&R is a stop point during long distance journey that have a well maintained facilities and service. It is located in every 8 to 100 $\mathrm{km}$ which the purpose is to make the expressway user more comfortable and as a rest area for tired travelers. Some amenities available are air-conditioned food court, Muslim prayer room, toilets, children playground, rest shelters, public phones, and petrol station. With all the good amenities offered and strategically located, this area usually will be packed with travelers especially during festive seasons and long school holidays.

\section{DATA ANALYSIS AND DISCUSSION}

\section{Demographic factors}

Based on the responses from the survey, a total of 384 respondents were categorized with PVFR, CVFR, EVFR and non-VFR. First section of questionnaire needs them to fill their demographic information. Table 1 show that output analysis of demographic factors of respondents which consist of Malaysian domestics travelers. Each respondent was categorized by the demographic factors with the total number and percentage that represent each category. The highest respondent gender was female's PVFR which represent 75 respondents from the total sample. Most respondents were between the ageof 31-40 years old and is a Malay. Apart from that, more than half of respondents were married and hold a degree certification. 


\section{Percentage of VFR travelers}

\begin{tabular}{lcc} 
& $\begin{array}{c}\text { Accommodation: } \\
\text { Friends \& Family }\end{array}$ & $\begin{array}{l}\text { Accommodation; } \\
\text { Commercial }\end{array}$ \\
\cline { 2 - 3 } $\begin{array}{l}\text { Purpose of visit: } \\
\text { VFR }\end{array}$ & VFR=297 & \\
Purpose of visit: & $\%=77.34 \%$ & Non-VFR=87, $\%=22.66 \%$ \\
Non-VFR & & \\
\hline
\end{tabular}

Figure 3: Percentage of Travelers

From the table above, $77.34 \%$ of total respondents travel with the purpose of visiting friends and relatives or having visiting friends and relatives as part of their activities. It left the other 87 as non-VFR which is either for business, leisure or other purposes. The result shows that it is true that VFR travelers actually represent bigger number than usually stated. It is because some of VFR traveler does not have visiting friends and relative as the purpose of visit. Some of them are having visiting friends and relatives as part of activity on their trip. Example is EVFR who visit friends and relatives for accommodation purpose and also CVFR who visit friends and relatives as part of activity for their trip with business or leisure purposes. Each VFR market's percentage will be described as below;

\begin{tabular}{lll} 
& Accommodation: & Accommodation; \\
& Friends \& Family & Commercial \\
Purpose of visit: & PVFR & CVFR \\
VFR & $\mathrm{n}=137$ & $\mathrm{n}=109$ \\
& $\mathrm{n} \%=35.7$ & $\mathrm{n} \%=28.4$ \\
Purpose of visit: & EVFR & Non-VFR \\
Non-VFR & $\mathrm{n}=51$ & $\mathrm{n}=87$ \\
& $\mathrm{n} \%=13.3$ & $\mathrm{n} \%=22.6$ \\
\hline
\end{tabular}

Figure 4: Percentage of Travelers by VFR Market Segments

PVFR market was dominating the whole respondents in which represent 35.7 percent of total sample. It is followed by CVFR market and non-VFR market. EVFR market which has not having visiting friends and relatives as purpose is smallest market which only about 13.3 percent of respondent. 
Sharifah Eisyahtun Syed Darar \& Hairul Nizam Ismail

Tripographic Assessment of VFR Travel in Context of Malaysian Domestic Travelers

Table 1: Demographic Analysis of Travelers by VFR Market segments

\begin{tabular}{|c|c|c|c|c|c|c|c|c|c|}
\hline \multirow{2}{*}{\multicolumn{2}{|c|}{$\begin{array}{c}\text { DEMOGRAPHIC } \\
\text { N=384 } \\
\mathbf{N \%}=\mathbf{1 0 0 \%}\end{array}$}} & \multicolumn{8}{|c|}{ VFR TYPOLOGIES } \\
\hline & & & & & & & & & \\
\hline & & \multicolumn{2}{|c|}{$\begin{array}{c}\text { PVFR } \\
\text { n= 137 } \\
\text { n\% }=\mathbf{3 5 . 7 \%}\end{array}$} & \multicolumn{2}{|c|}{$\begin{array}{c}\text { CVFR } \\
\mathrm{n}=109 \\
\mathrm{n} \%=28.4\end{array}$} & \multicolumn{2}{|c|}{$\begin{array}{c}\begin{array}{c}\text { EVFR } \\
\text { n=51 } \\
\text { n\% }\end{array}=13.3 \%\end{array}$} & \multicolumn{2}{|c|}{$\begin{array}{c}\text { NON-VFR } \\
n=87 \\
n \%=22.6 \%\end{array}$} \\
\hline & & $\%$ & Count & $\%$ & Count & $\%$ & Count & $\%$ & Count \\
\hline \multirow[t]{2}{*}{ Gender } & Male & $45.3 \%$ & 62 & $\begin{array}{c}49.5 \\
\%\end{array}$ & 54 & $\begin{array}{c}43.1 \\
\%\end{array}$ & 22 & $55.2 \%$ & 48 \\
\hline & Female & $54.7 \%$ & 75 & $\begin{array}{c}50.5 \\
\%\end{array}$ & 55 & $\begin{array}{c}56.9 \\
\%\end{array}$ & 29 & $44.8 \%$ & 39 \\
\hline \multirow[t]{5}{*}{ Age } & $<20$ & $10.9 \%$ & 15 & $2.8 \%$ & 3 & $.0 \%$ & 0 & $10.3 \%$ & 9 \\
\hline & $20-30$ & $23.4 \%$ & 32 & $\begin{array}{c}22.0 \\
\%\end{array}$ & 24 & $\begin{array}{c}19.6 \\
\%\end{array}$ & 10 & $31.0 \%$ & 27 \\
\hline & $31-40$ & $22.6 \%$ & 31 & $\begin{array}{c}21.1 \\
\%\end{array}$ & 23 & $\begin{array}{c}45.1 \\
\%\end{array}$ & 23 & $37.9 \%$ & 33 \\
\hline & $41-50$ & $27.0 \%$ & 37 & $\begin{array}{c}40.4 \\
\%\end{array}$ & 44 & $\begin{array}{c}17.6 \\
\%\end{array}$ & 9 & $13.8 \%$ & 12 \\
\hline & $\begin{array}{l}51 \text { and } \\
\text { above }\end{array}$ & $16.1 \%$ & 22 & $\begin{array}{c}13.8 \\
\%\end{array}$ & 15 & $\begin{array}{c}17.6 \\
\%\end{array}$ & 9 & $6.9 \%$ & 6 \\
\hline \multirow[t]{4}{*}{ Races } & Malay & $83.9 \%$ & 115 & $\begin{array}{c}71.6 \\
\%\end{array}$ & 78 & $\begin{array}{c}76.5 \\
\%\end{array}$ & 39 & $75.9 \%$ & 66 \\
\hline & Chinese & $13.9 \%$ & 19 & $\begin{array}{c}22.9 \\
\%\end{array}$ & 25 & $\begin{array}{c}11.8 \\
\%\end{array}$ & 6 & $20.7 \%$ & 18 \\
\hline & Indian & $2.2 \%$ & 3 & $5.5 \%$ & 6 & $\begin{array}{c}11.8 \\
\%\end{array}$ & 6 & $3.4 \%$ & 3 \\
\hline & Others & $.0 \%$ & 0 & $.0 \%$ & 0 & $.0 \%$ & 0 & $.0 \%$ & 0 \\
\hline \multirow[t]{4}{*}{$\begin{array}{l}\text { Marital } \\
\text { status }\end{array}$} & Single & $35.0 \%$ & 48 & $\begin{array}{c}13.8 \\
\%\end{array}$ & 15 & $5.9 \%$ & 3 & $20.7 \%$ & 18 \\
\hline & Married & $56.9 \%$ & 78 & $\begin{array}{c}86.2 \\
\%\end{array}$ & 94 & $\begin{array}{c}78.4 \\
\%\end{array}$ & 40 & $79.3 \%$ & 69 \\
\hline & Divorced & $3.6 \%$ & 5 & $.0 \%$ & 0 & $7.8 \%$ & 4 & $.0 \%$ & 0 \\
\hline & Widowed & $4.4 \%$ & 6 & $.0 \%$ & 0 & $7.8 \%$ & 4 & $.0 \%$ & 0 \\
\hline $\begin{array}{l}\text { Educati } \\
\text { on }\end{array}$ & SPM & $17.5 \%$ & 24 & $\begin{array}{c}19.3 \\
\%\end{array}$ & 21 & $\begin{array}{c}23.5 \\
\%\end{array}$ & 12 & $34.5 \%$ & 30 \\
\hline \multirow[t]{4}{*}{ Level } & $\begin{array}{l}\text { STPM/Dip } \\
\text { loma/ } \\
\text { Etc... }\end{array}$ & $29.9 \%$ & 41 & $\begin{array}{c}17.4 \\
\%\end{array}$ & 19 & $7.8 \%$ & 4 & $13.8 \%$ & 12 \\
\hline & Degree & $36.5 \%$ & 50 & $\begin{array}{c}40.4 \\
\%\end{array}$ & 44 & $\begin{array}{c}51.0 \\
\%\end{array}$ & 26 & $27.6 \%$ & 24 \\
\hline & $\begin{array}{l}\text { Master \& } \\
\text { Profession } \\
\text { al }\end{array}$ & $6.6 \%$ & 9 & $6.4 \%$ & 7 & $5.9 \%$ & 3 & $10.3 \%$ & 9 \\
\hline & Others & $9.5 \%$ & 13 & $\begin{array}{c}16.5 \\
\% \\
\end{array}$ & 18 & $\begin{array}{c}11.8 \\
\% \\
\end{array}$ & 6 & $13.8 \%$ & 12 \\
\hline
\end{tabular}

\section{Travel frequencies}

\begin{tabular}{lcc} 
& $\begin{array}{c}\text { Accommodation: } \\
\text { Friends \& Family }\end{array}$ & \multicolumn{2}{c}{$\begin{array}{c}\text { Accommodation; } \\
\text { Commercial }\end{array}$} \\
\hline Purpose of visit: & PVFR & CVFR \\
VFR & 4.197 & 4.174 \\
Purpose of visit: & EVFR & Non-VFR \\
Non-VFR & 3.882 & 3.000 \\
\hline
\end{tabular}

Figure 5: Travel Frequencies by VFR Market Segments 
The table above shows that the travel frequencies of each market tested. As they were asked on how many times visiting Johor yearly, PVFR has the high numbers of frequency. With the purpose of visiting friends and relatives as the major purpose, it is proving that the social relationship with family or/and friend is important socially as a travel motive (Jensen, n.d.). It is also supported by other VFR market segment which stated higher number of frequencies as compared to non-VFR travelers which stating only 3.000 yearly.

\section{Commercial accommodation}

\begin{tabular}{|cc|}
\hline Accommodation:nFriends \& Family & Accommodation; Commercial \\
\hline PVFR & CVFR \\
$\mathrm{n}=137$ & $\mathrm{n}=109$ \\
$\mathrm{n} \%=35.7$ & $\mathrm{n} \%=28.4$ \\
\hline $\mathrm{EVFR}$ & $\mathrm{Non}-\mathrm{VFR}$ \\
$\mathrm{n}=51$ & $\mathrm{n}=87$ \\
$\mathrm{n} \%=13.3$ & $\mathrm{n} \%=22.6$ \\
\hline
\end{tabular}

Figure 6: Accommodation Used by VFR Market Segments

Navarro \& Turco (1994) explained that one factor that made the VFR market neglected is the perception of this market that they utilizing the commercial accommodation in a very small scale. The above figure shows that more then a quarter of respondents were using commercial accommodation. In fact, their group represents higher number as compared to other travelers with other purpose of trip. It can be concluded that the trend of VFR using friends and family accommodation has been changed slightly since their preference of accommodation turns into using the commercial one. Some of reasons for this changed is the independence of trip planning besides they prefer to stay privately from others.

\section{TRAVELER'S EXPENDITURE}

As stated before in reason for the neglect of this market, it was assumed that it does not give a big economic impact on the area that they visited and also was over looked by destination marketing organization as one of potential market. The result was turn surprisingly as table 2 below. Each of respondent stated the average daily spend on each sector based on the activity that they have been participated. Surprisingly, the exploit VFR spent most compared to non-VFR and other VFR market. They are not utilizing commercial accommodation however spend most at shopping and visiting destination attraction. Even though their main purpose is not visiting friends and relatives, they spent large amount of money. Compared to VFR markets, they also spent higher on dining out which mean that even though they stayed with family or friend, they dine out mostly. However, when it comes to accommodation, non-VFR possess the higher spent but does not have great different compare to commercial VFR market. 
Sharifah Eisyahtun Syed Darar \& Hairul Nizam Ismail

Tripographic Assessment of VFR Travel in Context of Malaysian Domestic Travelers

Table 2: Travelers Expenditure by VFR Market Segments

\begin{tabular}{|c|c|c|c|c|}
\hline \multicolumn{5}{|c|}{ EXPENDITURE } \\
\hline & \multicolumn{4}{|c|}{ Typologies } \\
\hline & $\begin{array}{c}\text { PVFR } \\
\text { N=137 } \\
\mathbf{N} \%=\mathbf{3 5 . 7 \%}\end{array}$ & $\begin{array}{c}\text { CVFR } \\
\mathrm{N}=109 \\
\mathbf{N} \%=28.4\end{array}$ & $\begin{array}{c}\text { EVFR } \\
N=51 \\
\text { N\% }=13.3 \%\end{array}$ & $\begin{array}{c}\text { NON-VFR } \\
N=87 \\
\text { N\% }=22.6 \%\end{array}$ \\
\hline & Mean & Mean & Mean & Mean \\
\hline Accommodation & 0 & 191 & 0 & 201 \\
\hline Dining Out & 82 & 85 & 119 & 138 \\
\hline Public Transport & 4 & 23 & 18 & 23 \\
\hline Visiting Attraction & 72 & 41 & 180 & 178 \\
\hline Entertainment & 13 & 29 & 25 & 28 \\
\hline Shopping & 202 & 112 & 321 & 163 \\
\hline Groceries & 80 & 25 & 21 & 18 \\
\hline Fuel & 134 & 86 & 124 & 178 \\
\hline Toll Fees & 30 & 15 & 30 & 40 \\
\hline Other & 1 & 0 & 0 & 31 \\
\hline TOTAL & 618 & 607 & 838 & 807 \\
\hline
\end{tabular}

\section{Preliminary Findings and VFR Definitional Model}

Disaggregating the VFR travelers market by the definitional model give a picture of characteristics of each proposed type. Firstly, it support that the number of VFR travelers were actually bigger than it was stated by classifying another type of VFR Traveler which is EVFR. The classification of travelers or tourist by the only purpose of visit will actually disregard one potential VFR market with other purpose of visit such as business and leisure which called EVFR. Apart from that, all VFR travelers seem to travel more compared to non-VFR. PVFR are the most one because it support the statement that is a Malaysian tradition which is 'BalikKampung' or return to hometown (Unwto, 2013).

Apart from that, by applying another type of CVFR market segment, it is a proof that pattern of VFR trip does not mean by only staying with friend or family only. They would be acting aggressively since they have the independence on planning and moving during their trip. However, results shows that travelers who stayed with family or friends were actually spend more compared to CVFR. In fact, EVFR are the ones who spent more compared to non-VFR. All the results have shown that the assumption of VFR travel area acting passively was untrue since most of the characteristics almost the same with other markets. By disaggregating them, the result much clearer and their characteristics can be determined more easily compared to classifying them as one segment only.

\section{LIMITATION OF RESEARCH}

As Malaysia holds many holidays and festive seasons with different kind of races, people tend to move out from their daily routines and travel more with many motives, each holiday and season will reflect different kind of trip characteristics. Each race also has different behavior during their journey.

Apart from this, even though this research population is Malaysian domestics travel market, the result appeared was only reflects on one state only which is in this case 
is Johor. Other states that has different infrastructure and amenities besides tourism attraction might giving different characteristics especially on the spending patterns of travelers.

\section{CONCLUSIONS}

As VFR market tend to be assumed as passive market before, today's VFR travelers characteristics seems to be contributing to economy and tourism industry. The number of them actually bigger than it was stated since the market was disaggregated by purpose of travel and accommodation used. Also, all the VFR market that was disaggregated also travel frequently compared to non-VFR. This result shows that visiting friends and relatives is one of motive that will make people travel more compare to other motives. Apart from that, the tradition of staying with family or friends during a trip for visiting them seem to be blew since the number of VFR travelers staying at commercial accommodation were quite high. Even they spent less money on accommodation compared to non-VFR market, they did give an impact on commercial accommodation economically. However, VFR markets with the purpose of visiting friends and relatives do spent less as compared to non-VFR, the exploit VFR market spent the most compared to other markets. Not spending on accommodation made them spent more on other activities. It can be concluded that VFR market were actually have a bigger impact not only socially but also in economy and tourism industry.

\section{THE FUTURE RESEARCH OF VFR TRAVEL}

In context of Malaysian, there is less number of researches that give a picture of VFR travel. As stated before, this market represents 46 percent of total domestic travelers which is a great figure. A deep research on this potential market should be done to have a better understanding on them. As the trip characteristics can be surface information about this market, some of research can be done as proposed below;

\section{The spending patterns}

The expenditure of VFR travelers is complicated since the trip involving three parties which is the travelers, host and tourism operators. The pattern might include travelers spend on tourism operator, travelers spend on host and the host spend on travelers.

\section{VFR travel motive}

Even though the motive for travelling is visiting friends and relatives, there are some factors or reasons that made them visit their family or friends. Specifically it questioned why they pay them a visit. Some model or factors can be building to determine the VFR travel motives.

\section{Host involvement}

As some of characteristics of VFR traveler already been described, host information and involvement also worth to be interpreted. This is because they are the ones who can influence the travelers directly on their characteristics and behavior during their trip. 
Sharifah Eisyahtun Syed Darar \& Hairul Nizam Ismail

Tripographic Assessment of VFR Travel in Context of Malaysian Domestic Travelers

\section{Destination marketing towards the VFR travel}

The result show that VFR travelers do give an impact towards the economy, some study can be conducted to assess the marketing operation towards this market. The study could be the measurement of the awareness towards this market and also tools used for assessing the VFR travelers. Destination marketing organization and tourism player should have a better understanding on them since their contribution undisputed.

\section{REFERENCES}

Backer, E. (2007). VFR Travel: An Examination of the Expenditures of VFR Travellers andtheir Hosts. Current Issues in Tourism, 10(4), 366-377. doi:10.2167/cit277.0

Backer, E. R. (2010). VFR travel : an assessment of VFR versus non-VFR travellers.

Braunlich, C. G., \& Nadkarni, N. (1995). The Importance of the VFR Market to the Hotel Industry. Journal of Tourism Studies, 6(1), 38-47.

Griffin, T. (2013). Research Note: A Content Analysis of Articles on Visiting Friends and Relatives Tourism, 1990-2010. Journal of Hospitality Marketing \& Management, 22(7), 781-802. doi:10.1080/19368623.2012.708960

Hu, B., \& Morrison, a. M. (2002). Tripography: Can destination use patterns enhance understanding of the VFR market? Journal of Vacation Marketing, 8(3), 201-220.

International Recommendations for Tourism Statistics. (2008), (83).

Jackson, R. T. (2003). VFR Tourism : Is It Underestimated ?, 14(1), 17-24..

Jensen, J. M. (n.d.). The relationships between socio-demographic variables, travel motivations and subsequent choice of vacation.

Morrison, A. M., \& Leary, J. T. O. (1993).The VFR Market: Desperately Seeking Respect, 6(1), 2-5.

Morrison, A. M., \& Leary, J. T. O. (n.d.). Segmenting the Visiting Friends and Relatives Market By Holiday Activity Participation, 6(1).

Navarro, R. L. . J., \& Turco, D. M. (1994). Segmentation of the visiting friends and relatives travel market. Visions in Leisure and Business, 13(1), 4-16.

Paci, E. (1994). The major international VFR markets. Travel \& Tourism Analyst, 6, 3650.

Ramachandran, S. (2006). Visiting Friends and Relatives ( VFR ) Market : A Conceptual Framework, 3(1), 1-10.

Seaton, A., \& Palmer, C. (1997). Understanding VFR tourism behaviour: the first five years of the United Kingdom tourism survey. Tourism Management, 18(6), 345355.

Unwto. (2013). Domestic Tourism in Asia and the Pacific. Madrid

Wu, L., Zhang, J., \& Fujiwara, A. (2011). Representing tourists' heterogeneous choices of destination and travel party with an integrated latent class and nested logit model. Tourism Management, 32(6), 1407-1413. doi:10.1016/j.tourman.2011.01.017 